\title{
26. SR-ISOTOPE RATIOS ON WHOLE-ROCK SAMPLES OF LEG 45 BASALTS
}

\author{
V. v. Drach, D. Müller-Sohnius, H. Köhler, and H. G. Huckenholz, Mineralogisch-Petrographisches Institut \\ der Universität München, Theresienstr. 41, D-8000 Munchen 2, F.R.G.
}

\section{INTRODUCTION}

At Site $395\left(22^{\circ} 45.35^{\prime} \mathrm{N}, 46^{\circ} 04.90^{\prime} \mathrm{W}\right)$, situated on magnetic anomaly 4 (upper Miocene) on the western flank of the Mid-Atlantic Ridge, 572 meters of igneous basement rocks were drilled in Hole 395A and 95 meters in Hole 395. The borehole penetrates several units of aphyric and porphyritic basalts which exhibit in part reversals of magnetic inclination. The basalts are overlain at Site 395 by a Pleistocene to upper Miocene sequence of calcareous ooze about 100 meters thick.

The first investigations of the ${ }^{87} \mathrm{Sr} /{ }^{86} \mathrm{Sr}$ ratios of the cored basalts, we selected nine samples (two from Hole 395 , seven from Hole 395A) from a series of about 80 samples available in Munich. These selected samples belong to four different basaltic units, of which the upper two show positive and the two lower show negative magnetic inclination. A corresponding alternation in grain size occurs. We chose the freshest basalts from the sample series available for each investigated unit. The fifth sample came from the uppermost of these units. Half of this sample shows moderate alteration, and the other half appears to be quite fresh. The two halves were separated for the analysis.

Our objectives in measuring the ${ }^{87} \mathrm{Sr} / 86 \mathrm{Sr}$ ratio of the ocean floor basalts drilled on Leg 45 were as follows:

1) To see whether there are significant differences in the isotopic composition of strontium in the different basaltic units. These differences could reflect changes in the source regions of the basalts with time, assuming that they originated in an inhomogeneous upper mantle.

2) To see whether the strontium isotope ratios differ between the fresh and the altered samples, and if so, how these differences can be explained by seawater interaction.

\section{SAMPLE PREPARATION AND ANALYTICAL PROCEDURE}

Parts of the samples weighing 12 to 17 grams were first crushed to pieces less than $0.5 \mathrm{~cm}$ in size, then washed 5 minutes with distilled water in an ultrasonic bath. In a few cases black glue spots were removed with trichlorethylene and acetone before washing. The pieces were ground in a tungsten carbide ring mill for 0.5 minute and the powder split with a riffle to about 0.5 -gram aliquots. Sample 510 was split into two 7 -gram halves before grinding to facilitate the separation of plagioclase for later analysis.
The final aliquots were dissolved with hydrofluoric plus perchloric acid in teflon cups, and strontium was eluted in ion-exchange columns with Dowex 50WX8. The total Sr-blank is about $6 \mathrm{ng}$.

The isotope measurements were carried out on a Varian MAT CH4 mass spectrometer with an On-Line calculation system (Müller-Sohnius et al., 1974). The sample (about $1 \mu \mathrm{g} \mathrm{Sr}$ ) was loaded on a double tantalum filament source. The filament was coated with $\mathrm{Ta}_{2} \mathrm{O}_{5}$ to enhance intensity. A faraday cup was used as detector. The range for $88 \mathrm{Sr}$ was 0.2 to $2 \mathrm{~V}$, using an input resistor of $10^{10} \Omega$. The single $\mathrm{Sr}$ isotopic ratios were measured 300 to 800 times for each sample, in order to obtain sufficient precision for the mean value.

Measurements of the Eimer and Amend and the NBS $\mathrm{SrCO}_{3}$ standards are included in Table 1. From the duplicate analysis we can assume $2 \times 10^{-4}$ for the reproducibility of our basalt ${ }^{87} \mathrm{Sr} /{ }^{86} \mathrm{Sr}$ data on the 95 per cent confidence level.

\section{RESULTS AND DISCUSSION}

The results of the Sr-isotope measurements (mean of two or three separate determinations) of the basalt samples are given in Table 1 . The $\mathrm{Sr}$ - and $\mathrm{Rb}$-concentration values, which were measured with XRF on aliquots, are taken from Propach et al., (this volume).

The measured $\mathrm{Sr}$-isotope ratios for the fresh basalts fall within the range obtained by various workers for dredged or drilled mid-ocean ridge tholeiites (review given by Hofmann and Hart, 1975).

Our isotope ratios do not differ significantly for the fresh basalts from Hole $395 \mathrm{~A}$, but seem to be slightly lower for the basalts from Hole 395 . The significance of these two lower values has to be tested by further measurements. Consequently, if there is any variation in the ${ }^{87} \mathrm{Sr} /{ }^{86} \mathrm{Sr}$ initial ratio for the Leg 45 basalts, it is no more than 0.0005 , given by the two most extreme results (Samples $507 \mathrm{~F}$ and 580 ). Thus, Sr-isotoperelated inhomogeneities in the upper mantle source region of the Leg 45 rocks do not exceed this value.

Altered Sample 507a shows a significantly higher ${ }^{87} \mathrm{Sr} /{ }^{86} \mathrm{Sr}(0.70351 \pm 5)$ than the fresh samples (average value: $0.70275 \pm 12$ ). This is what one would expect if interaction had occurred between the $\mathrm{Sr}$ of the basalt and that of the seawater. Such effects related to Srisotopes have been studied on other deep-sea basalts by Dasch et al. (1973) and Hart et al. (1974).

The oxygen isotope ratios, measured by Hoernes et al. (this volume) show that a strong interaction has 
V. V. DRACH, D. MÜLLER-SOHNIUS, H. KÖHLER, H. G. HUCKENHOLZ

TABLE 1

Strontium Isotope Ratios on Leg 45 Basalts and on Standards

\begin{tabular}{|c|c|c|c|c|c|c|}
\hline $\begin{array}{l}\text { Internal } \\
\text { No. }\end{array}$ & $\begin{array}{c}\text { Sample } \\
\text { (Interval in } \mathrm{cm} \text { ) }\end{array}$ & $\begin{array}{l}\text { Rb-Conc. } \\
\text { (ppm) }\end{array}$ & $\begin{array}{l}\text { Sr-Conc. } \\
\quad(p p m)\end{array}$ & \multicolumn{2}{|c|}{${ }^{87} \mathrm{Sr} /{ }^{86} \mathrm{Sr}^{\mathrm{b}}$} & $\begin{array}{c}\text { Error } \\
\left(2 \sigma_{\text {Mean }}\right)\end{array}$ \\
\hline \multicolumn{7}{|c|}{ Leg 45 Basalts } \\
\hline \multirow[t]{2}{*}{506} & $395 \mathrm{~A}-09-2,17-28$ & 5.5 & 121 & & $\begin{array}{l}0.70257 \\
0.70266\end{array}$ & $\begin{array}{l}0.00010 \\
0.00005\end{array}$ \\
\hline & & & & mean & 0.70264 & +0.00006 \\
\hline \multirow[t]{2}{*}{$507 \mathrm{f}$} & $395 \mathrm{~A}-11-1,56-66$ & 6.5 & 127 & & $\begin{array}{l}0.70289 \\
0.70293\end{array}$ & $\begin{array}{l}0.00018 \\
0.00013\end{array}$ \\
\hline & & & & mean & 0.70292 & 0.00011 \\
\hline \multirow[t]{2}{*}{$507 \mathrm{a}$} & $395 A-11-1,56-66$ & 8.4 & 159 & & $\begin{array}{l}0.70348 \\
0.70357 \\
0.70356 \\
0.70337\end{array}$ & $\begin{array}{l}0.00007 \\
0.00007 \\
0.00025 \\
0.00016\end{array}$ \\
\hline & & & & mean & 0.70351 & 0.00005 \\
\hline \multirow[t]{2}{*}{510} & $395 \mathrm{~A}-14-1,87-99$ & 5.8 & 150 & & $\begin{array}{l}0.70272 \\
0.70278\end{array}$ & $\begin{array}{l}0.00023 \\
0.00009\end{array}$ \\
\hline & & & & mean & 0.70277 & 0.00008 \\
\hline \multirow[t]{2}{*}{537} & $395 \mathrm{~A}-46-1,88-94$ & 6.0 & 126 & & $\begin{array}{l}0.70285 \\
0.70299\end{array}$ & $\begin{array}{l}0.00009 \\
0.00015\end{array}$ \\
\hline & & & & mean & 0.70289 & 0.00008 \\
\hline \multirow[t]{2}{*}{542} & $395 \mathrm{~A}-52-1,45-50$ & 6.9 & 134 & & $\begin{array}{l}0.70270 \\
0.70272\end{array}$ & $\begin{array}{l}0.00007 \\
0.00005\end{array}$ \\
\hline & & & & mean & 0.70271 & 0.00004 \\
\hline \multirow[t]{2}{*}{544} & $395 A-56-3,47-55$ & 8.8 & 125 & & $\begin{array}{l}0.70305 \\
0.70285 \\
0.70306\end{array}$ & $\begin{array}{l}0.00003 \\
0.00012 \\
0.00007\end{array}$ \\
\hline & & & & mean & 0.70304 & 0.00003 \\
\hline \multirow[t]{2}{*}{549} & $395 \mathrm{~A}-61-2,75-85$ & 6.4 & 135 & & $\begin{array}{l}0.70285 \\
0.70262 \\
0.70273\end{array}$ & $\begin{array}{l}0.00013 \\
0.00008 \\
0.00018\end{array}$ \\
\hline & & & & mean & 0.70269 & 0.00007 \\
\hline \multirow[t]{2}{*}{572} & $395-11-2,110-116$ & 7.5 & 118 & & $\begin{array}{l}0.70234 \\
0.70260 \\
0.70248\end{array}$ & $\begin{array}{l}0.00016 \\
0.00009 \\
0.00009\end{array}$ \\
\hline & & & & mean & 0.70251 & 0.00006 \\
\hline \multirow[t]{2}{*}{580} & $395-19-1,135-138$ & 5.7 & 151 & & $\begin{array}{l}0.70245 \\
0.70244 \\
0.70258\end{array}$ & $\begin{array}{l}0.00011 \\
0.00022 \\
0.00012\end{array}$ \\
\hline & & & & mean & 0.70250 & 0.00008 \\
\hline \multicolumn{2}{|c|}{$\mathrm{SrCO}_{3}$-Standards } & & & & 0.71032 & 0.00015 \\
\hline \multicolumn{2}{|c|}{ Eimer and Amend } & & & & $\begin{array}{l}0.70820 \\
0.70812 \\
0.70811\end{array}$ & $\begin{array}{l}0.00007 \\
0.00006 \\
0.00007\end{array}$ \\
\hline
\end{tabular}

${ }^{\mathrm{a}}$ Data from Propach et al. (this volume).

${ }^{b}$ Normalized with ${ }^{88} \mathrm{Sr} /{ }^{86} \mathrm{Sr}=8.3752$; no age correction was made for ${ }^{87} \mathrm{Sr} /{ }^{86} \mathrm{Sr}$, because the enrichment of ${ }^{87} \mathrm{Sr}$ from the decay of ${ }^{87} \mathrm{Rb}$ in the basalts is less than 0.00003 for their assumed upper Miocene age.

occurred between the basalt matrices and sea water at low temperatures. This interaction has affected even the rocks we regard as fresh. The Sr content of the altered sample is about 12 per cent higher than that of its fresh counterpart, and about 18 per cent higher than that of Sample 506 (Table 1), which belongs to the same basaltic unit as 507. Calculations show that the higher Sr content of 507a need not necessarily be a result of Sr-isotope exchange, but can also simply be attributable to an addition of seawater $\mathrm{Sr}$, which had a
${ }^{87} \mathrm{Sr} / 86 \mathrm{Sr}$ ratio of about 0.709 in the upper Miocene (Peterman et al., 1970). Some of the apparently fresh basalts (e.g., Sample 507f) may have been enriched in ${ }^{87} \mathrm{Sr}$ by seawater contamination to a lesser extent than is evident in Sample 507a. This effect might, in some cases, simulate small variations in the Sr-isotope initial ratios of the basalts.

As can be seen from the Site Chapters (this volume), more than 50 per cent of the recovered basalt core is moderately or even badly altered. Ex- 
trapolating the results of our measurements on the altered Sample $507 \mathrm{a}$, we conclude that the average ${ }^{87} \mathrm{Sr} /{ }^{86} \mathrm{Sr}$ ratio for the whole basaltic pile is significantly higher than that of the originally unaltered basalts. Any considerations of the isotopic evolution trends of ocean floor basalts have to take seawater alteration into account. This may be an explanation for the provenance of the relatively higher $\mathrm{Sr}$-isotope ratios found in andesites (e.g., 0.7037: Dickinson, 1970), which are believed to have been formed by melting along arc-trench subduction zones. More work has to be done in this direction.

\section{ACKNOWLEDGMENTS}

The authors wish to thank Stuart Lee for his help in selecting and prepararing the samples and for revision of the manuscript. Furthermore, we thank Dr. E. Prosser and the other members of the shipboard crew for providing us with excellent samples for our investigations. This work was supported by the Deutsche Forschungsgemeinschaft.

\section{REFERENCES}

Dasch, E. J., Hedge, C. E., and Dymond, J. 1973. Effect of sea water interaction on strontium isotope composition of deep-sea basalts, Earth Planet. Sci. Lett., v. 19, p. 177183.

Dickinson, W. R., 1970. Relations of andesites, granites and derivative sandstones to arc-trench tectonics, Rev. Geophys. Space Phys., v. 8, p. 813-860.

Hart, S. R., Erlank, A. J., and Kable, E. J. D., 1974. Sea floor basalt alteration: some chemical and $\mathrm{Sr}$ isotopic effects, Contrib. Mineral. Petrol., v. 44, p. 219-230.

Hofmann, A. W. and Hart, S. R., 1975. An assessment of local and regional isotopic equilibrium in a partially molten mantle, Carnegie Inst. Wash. Year Book, v. 74, p. 195-210.

Müller-Sohnius, D., Cammann, K. and Köhler, H., 1974. The use of a desk calculator for the On-Line measurement of isotopic abundances, Int. J. Mass Spectr. Ion Phys., v. 15, p. 155-164.

Noussinanos, T., 1973. Geochemie und Petrologie Oberpfälzer Olivinnephelinite und ihrer Ultramafiteinschlüsse. Unpublished Ph.D. dissertation, Fak. Geowiss., Universität München.

Peterman, Z. E., Hedge, C. E., and Tourtelot, H. A., 1970. Isotopic composition of strontium in sea water during Phanerozoic time, Geochim. Cosmochim. Acta., v. 34, p. 105-120. 